\title{
DAMPAK KREATIVITAS DAN INOVASI PRODUK TERHADAP KINERJA UKM DI KOTA SEMARANG
}

\author{
Kalil $^{1}$, Evant Andi Aenurohman ${ }^{1}$ \\ ${ }^{1}$ Fakultas Ekonomika dan Bisnis Universitas Diponegoro \\ Jl. Hayam Wuruk No. 5 Semarang \\ Email \& Phone: kalil@student.undip.ac.id \& 081578000525
}

Submitted: 2019-08-05

Accepted: 2020-01-31

Published: 2020-02-01

\begin{tabular}{ll}
\hline Keywords: & Abstract \\
\hline Creativity & SME is one of the backbones of the national economy that \\
Procut Innovation & directly faces the competition of the ASEAN Economic \\
Business & Community (AEC). The role of SMEs as economic activities \\
Performance & is expected not only to be able to meet market needs in local \\
SMEs & communities but also reduce unemployment by providing \\
& employment. The purpose of this study was to determine the \\
& effect of creativity and product innovation on business \\
performance. This research is field research for \\
businesspeople in the city of Semarang. The sample was \\
selected using a purposive sampling approach, a business \\
actor (owner or manager) who is willing to be a respondent \\
as many as 100 respondents. The results of this study indicate \\
that creativity and product innovation simultaneously have a \\
positive and significant effect on the business performance of \\
SMEs in the city of Semarang. The implications of this \\
research can be used by SMEs to optimize creativity and \\
improve product innovation capabilities so that it has an \\
impact on improving performance.
\end{tabular}

\begin{tabular}{ll}
\hline Kata kunci & Abstrak \\
\hline Kreativitas & UKM adalah salah satu tulang punggung perekonomian \\
Inovasi Procut & nasional yang secara langsung menghadapi persaingan \\
Performa Bisnis & Masyarakat Ekonomi ASEAN (MEA). Peran UKM sebagai \\
UKM & kegiatan ekonomi diharapkan tidak hanya untuk dapat \\
& memenuhi kebutuhan pasar di masyarakat lokal, tetapi juga \\
& mengurangi pengangguran dengan menyediakan lapangan \\
& kerja. Tujuan penelitian ini adalah mengetahui pengaruh \\
& kreativitas dan inovasi produk terhadap kinerja bisnis. \\
& Penelitian ini adalah penelitian lapangan untuk pengusaha \\
& di kota Semarang. Sampel dipilih menggunakan pendekatan \\
& purposive sampling, pelaku usaha (pemilik atau manajer) \\
& yang bersedia menjadi responden sebanyak 100 responden. \\
& Hasil penelitian ini menunjukkan bahwa kreativitas dan \\
& inovasi produk secara simultan memiliki pengaruh positif \\
\hline
\end{tabular}


dan signifikan terhadap kinerja bisnis UMKM di kota

Semarang. Implikasi dari penelitian ini dapat digunakan oleh

UKM untuk mengoptimalkan kreativitas dan meningkatkan kemampuan inovasi produk sehingga berdampak pada peningkatan kinerja.

\section{PENDAHULUAN}

Keputusan pemerintah ketika mengumumkan Masyarakat Ekonomi ASEAN (MEA) pada tahun 2015 memunculkan kesempatan dalam berwirausaha. Datangnya ancaman pesaing dari luar menjadi tantangan tersendiri bagi perekonomian di Indonesia khususnya Usaha Kecil dan Menengah (UKM). Munculnya kebijakan pasar bebas dalam cakupan lebih luas yang menjangkau negara di Asia Tenggara otomatis akan berdampak pada munculnya berbagai kegiatan ekonomi, seperti aliran bebas berbagai produk hingga investasi, massifnya tenaga kerja dengan kompetensi unggul dari berbagai negara yang terdaftar dalam anggota ASEAN. Diperlukan rencana yang tepat agar kemunculan MEA ini memberikan akibat yang positif, khususnya bagi UKM agar mampu berdaya saing dan menghasilkan produk unggul yang diserap oleh pasar.

Sebagai bagian tak terpisah dalam aktivitas perekonomian, keberadaan UKM harus mendapatkan perhatian khusus, pendampingan hingga ketersediaan modal yang cukup agar dapat bersaing dengan konglomerasi yang lebih besar. UKM sangat penting keberadaannya bagi masyarakat karena memiliki kemampuan dalam menyediakan lapangan kerja sekaligus menyerap tenaga kerja usia produktif yang menjangkau hingga pelosok desa, memberi kenaikan penghasilan bagi masyarakat, dan memiliki potensi menjadi aktivitas ekonomi unggulan regional.

Kondisi pasar yang pasang surut cenderung lebih mudah dihadapi oleh UKM dibandingkan usaha besar. Tidak hanya itu, kemampuan UKM juga telah teruji dengan berbagai krisis yang pernah melanda Indonesia. UKM terbukti berdaya dalam menyerap tenaga kerja secara lebih cepat jika dibandingkan sektor usaha lain, sehingga UKM adalah aset yang vital di dalam proses membangun ekonomi Indonesia yang kompetitif di masa depan (Hapsari, 2014).

Menurut Stel, et al., (2004) UKM memiliki peran utama dalam kegiatan ekonomi secara menyeluruh dalam suatu negara. Beberapa peran penting tersebut adalah menghadirkan lapangan kerja, menghadirkan pendapatan yang merata di masyarakat, menjangkau dan membangun perekonomian hingga ke pelosok pedesaan, serta mampu menjadi aktof penting dalam mendorong naiknya aktivitas ekspor nonmigas.

Dalam UU Nomor 20 Tahun 2008 dijelaskan beberapa poin penting yang menjadi arah dalam proses memberdayakan UKM, yaitu: (a) menciptakan struktur ekonomi yang seimbang, berkembang dan berkeadilan bagi semua, (b) mengembangkan kemampuan UKM agar berkembang dan menjadi usaha yang kuat, berdikari dan berdampak bagi masyarakat, dan (c) Meningkatkan fungsi UKM sebagai mitra dalam membangun perekonomian regional di daerah, menciptakan lapangan kerja, memberikan pendapatan yang merata, ekonomi yang tumbuh serta mampu menjadi mitra pemerintah dalam mengentaskan dari jerat kemiskinan di masyarakat.

Dalam Arah Kebijakan Bidang Koperasi dan UKM Kementerian KUKM yang disusun tahun 2018 terdapat fokus prioritas nasional pada penanggulangan kemiskinan dengan meningkatkan daya saing UKM dan koperasi dengan aktitivas utama, yaitu: (a) meningkatkan nilai suatu produk dan jalur untuk dipasarkan, (b) meningkatkan keahlian dalam memberikan pelayanan usaha, (c) meningkatkan jiwa kewirausahaan UKM, (d) memberikan kepastian dalam melindungi UKM, (e) memberikan kemudahan bagi UKM dalam mengakses permodalan, dan (f) koperasi dan mitra usaha. 
Pada tahun 2018 Kemenkop UKM merilis data terbaru mengenai jumlah pengusaha di Indonesia yang telah membukukan angka 3,1 persen dari keseluruhan jumlah penduduk Indonesia. Di atas kertas jumlah tersebut merupakan angka yang besar jika mengingkat standar internasional rasio ideal banyaknya pengusaha sebanyak dua persen. Namun, angka tersebut masih bisa dikatakan sedikit saat dibandingkan dengan banyaknya penduduk Indonesia tahun 2019 yang terhitung sebanyak 269,6 juta jiwa. Secara hitung-hitungan, jumlah pengusaha yang ada di Indonesia saat ini baru mencapai 8,34 juta jiwa. Pencapaian tersebut terhitung kecil jika melihat angka yang dicapai oleh negara tetangga, misalnya Singapura yang berhasil meraih skor 7 persen, sedangkan Malaysia sudah mencapai 5 persen. Berbagai upaya nyata pemerintah untuk meningkatkan angka ini dengan menggelontorkan berbagai program bagi pengusaha pemula dalam upaya meningkatkan kualitas UKM yang masih dalam tahap rintisan.

Menurut Barringer \& Ireland (2006) kreativitas dan inovasi adalah sentral utama dalam aktivitas usaha. Adanya kreativitas dan inovasi tidak dapat dipisahkan dari kewairausahaan, karena pada gilirannya akan diwujudkan dalam tindakan ketika menjalankan suatu perusahaan. Adapun menurut Kruger, Millard, \& Pretorius (2005) menyatakan bahwa kreativitas merupakan bagian dari keterampilan dalam berwirausaha yang dibutuhkan agar berhasil memulai usaha tersebut.

Menurut Bosma \& Harding (2006) seorang pengusaha dan sebuah usaha yang masih dalam tahap rintisan akan menjadi bagian penting dari munculnya inovasi, tidak hanya dalam hal produk dan layanan yang disediakan, tetapi juga dalam hal teknologi dan proses yang mereka gunakan. Pengusaha dapat memperlihatkan kemampuan mereka untuk menciptakan esensi kreativitas dan inovasi.

Seorang pengusaha mengaplikasikan gagasan baru dan kreatif untuk memperkenalkan adanya inovasi dalam sebuah produk atau layanan untuk memperoleh hasil produk dengan lebih efisien melui jalur inovatif. Inovasi dalam pengembangan produk baru bisa meningkatkan produk yang ada atau mengembangkan konsep yang benar-benar baru untuk menciptakan produk yang asli dan inovatif (Larsen \& Lewis, 2007).

Ada kesepakatan secara umum bahwa inovasi seharusnya hadir di semua aspek organisasi (perusahaan) dan inovasi tersebut harus menjadi pola pikir atau cara hidup secara keseluruhan semua yang terlibat dalam organisasi (Abraham \& Daniel, 2002). Inovasi harus menyebar ke dalam seluruh elemen organisasi, model bisnis untuk membuatnya lebih sulit untuk ditiru oleh pesaing (Loewe \& Dominiquini, 2006). Oleh karena itu, inovasi tidak hanya diukur oleh produk atau layanan baru yang ditawarkan oleh perusahaan, tetapi juga dalam aspek cara-cara baru dan lebih efisien dalam mengembangkan, memproduksi, atau memberikan produk atau layanan.

Disebutkan bahwa kreativitas tidak hanya diperlukan dalam hal pengembangan produk atau layanan baru, tetapi juga diperlukan oleh setiap jenis organisasi. Kreativitas dipandang sebagai hal yang melampaui produk baru, layanan baru dan proses baru yang lebih baik (Cook, 1998; Heye, 2006). Oleh karena itu, jika seseorang dapat mengatur dengan lebih baik atau menulis sebuah laporan dengan cara yang baru atau lebih efektif, semuanya ini dapat disebut sebagai tindakan kreatif (Gurteen, 1998).

UKM di Kota Semarang memegang peran penting dalam kegiatan perekonomian. Oleh karena itu berkembangnya UKM di sini diharapkan tidak hanya memberikan keuntungan bagi pengusaha, tetapi juga mampu menyelesaikan berbagai masalah sosial dan perekonomian: banyaknya kemiskinan, pengangguran terbuka yang terus meningkat dan adanya ketimpangan pendapatan jauh antara kaya dan miskin. Terdapat berbagai variabel yang menjadi penyebab kapabilitas UKM untuk mencapai kinerja tertinggi. Dua 
variabel yang dimaksud adalah kreativitas dan inovasi produk. Dua variabel tersebut diduga memiliki pengaruh positif dan signifikan terhadap kinerja UKM. Oleh karena itu, tujuan artikel ini adalah (1) mengetahui dampak atau pengaruh kreativitas terhadap kinerja usaha UKM di Kota Semarang, (2) menggali dampak atau pengaruh inovasi produk terhadap kinerja usaha UKM di Kota Semarang, dan (3) menggali dampak atau pengaruh kreativitas dan inovasi produk secara bersama-sama terhadap kemampuan atau kinerja usaha UKM di Kota Semarang.

\section{METODE PENELITIAN}

Penelitian ini menggunakan metode kuantitatif, yaitu suatu konsep penelitian yang diukur dengan menggunakan teknik yang menghasilkan angka-angka (Jonker et al., 2011). Populasi dalam penelitian ini adalah UKM di Kota Semarang yang fokus bisnisnya terletak pada bidang jasa dan perdagangan. Selain itu, responden yang dijadikan sampel dalam penelitian ini juga terdaftar di Dinas Koperasi dan UKM Kota Semarang. Pada penelitian ini subjek yang akan diteliti sebagian besar peneliti temukan di komunitas Tangan di Atas (TDA) Kota Semarang.

Data dikumpulkan melalui angket tertutup. Pertanyaan angket diberikan dengan opsi jawaban dengan aturan yang didasarkan pada skala Likert 5 poin. Seluruh jawaban ditabulasikan untuk kemudian dilakukan pengolahan lebih lanjut untuk diperoleh hasil dan simpulan. Variabel Kreativitas (X1) diukur dengan parameter: (1) Keterbukaan, (2) Unusual Observation, (3) Penemuan dan pengembangan ide baru, (4) Keinginan kuat untuk belajar. Variabel Inovasi Produk (X2) diukur dengan parameter: (1) Kelebihan produk baru, (2) Produk mudah dikenali, (3) Produk diterima oleh konsumen, (4) Pengembangan produk baru. Adapun variabel Kinerja Usaha (Y) diukur dengan parameter: (1) Pertumbuhan penjualan, (2) Pertumbuhan tenaga kerja, (3) Pertumbuhan pendapatan, dan (4) Pertumbuhan pangsa pasar.

Tahapan yang dilakukan berikutnya adalah uji validasi dan reliabilitas data, pengujian asumsi klasik, dan yang terakhir analisis regresi berganda. Konsep dalam penelitian ini ditunjukkan Gambar 1 berikut ini:

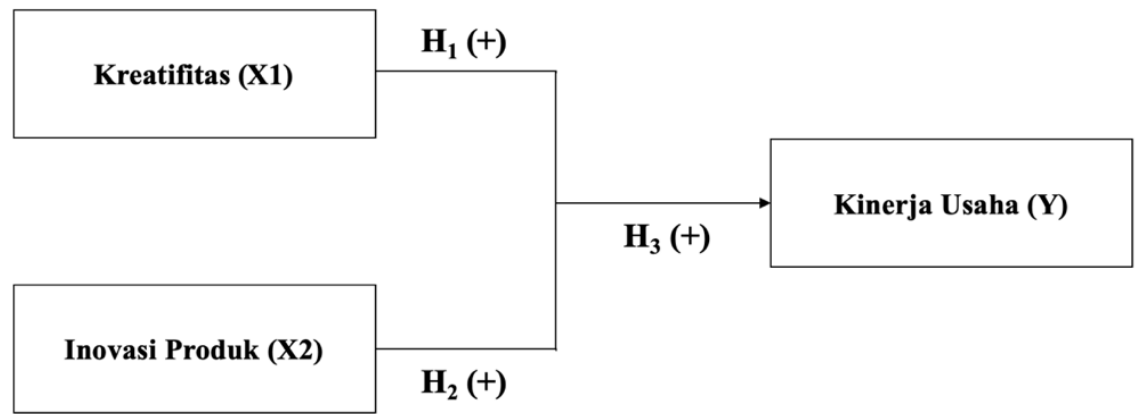

Gambar 1. Konsep Penelitian

Hipotesis penelitian:

1. Diduga kreativitas memberikan dampak atau pengaruh yang positif dan signifikan terhadap kinerja UKM di Kota Semarang.

2. Diduga inovasi produk memberikan dampak atau pengaruh yang positif dan signifikan terhadap kinerja UKM di Kota Semarang.

3. Diduga kreativitas dan inovasi produk secara simultan memberikan dampak atau pengaruh positif sekaligus signifikan terhadap kinerja UKM di Kota Semarang. 


\section{HASIL DAN PEMBAHASAN}

Berdasarkan hasil angkat yang didistribusikan kepada 100 orang subjek penelitian, dapat diuraikan profil UKM di Kota Semarang dalam penelitian ini yang meliputi berbagai kriteria, yaitu: usia responden, tingkat pendidikan, modal yang digunakan dalam memulai usaha, dan berapa lama usaha telah berjalan.

\section{Usia}

Dalam penelitian ini rentang usia pemilik atau pengelola UKM terdiri atas $49 \%$ berusia antara 20 sampai 30 tahun, $43 \%$ berusia antara 31 sampai 40 tahun, dan sebanyak $8 \%$ berusia lebih dari 50 tahun. Dapat disimpulkan bahwa mayoritas responden dalam penelitian ini sebanyak $43 \%$ berusia $31-40$ tahun.

\section{Tingkat Pendidikan}

Dalam penelitian ini, pendidikan pemilik atau pengelola usaha terdiri dari 3\% adalah tamatan SMP, 25\% merupakan tamatan SMA/SMK sederajat, 4\% merupakan tamatan Diploma, 59\% merupakan tamatan S1/D4, sedangkan 9\% merupakan tamatan S2/S3. Oleh karena itu, diketahui bahwa UKM jasa dan perdagangan di Kota Semarang dalam penelitian ini mayoritas merupakan lulusan S1/D4.

\section{Modal Usaha}

Modal usaha yang dimiliki oleh UKM di Kota Semarang dalam penelitian ini sebesar 16\% merupakan modal pinjaman baik dari lembaga keuangan ataupun pihak lain (investor), sedangkan sebesar $84 \%$ memulai usaha dengan modal sendiri. Dengan demikian, diketahui bahwa mayoritas UKM di Kota Semarang mengawali bisnis menggunakan modal sendiri.

\section{Lama Usaha}

Dalam penelitian ini, lama usaha UKM yang dikelola oleh masing-masing responden terdiri dari: $37 \%$ adalah usaha dengan umur kurang dari satu tahun, $42 \%$ usaha telah berjalan 1-5 tahun, sedangkan usaha yang usahanya telah berjalan lebih dari 10 tahun sebesar $21 \%$.

\section{Hasil Uji Validitas}

Hasil uji validitas menunjukkan semua instrumen variabel bernilai positif dan lebih besar dari $r$ tabel (0.195) yang artinya bahwa semua variabel yang digunakan dalam instrumen penelitian ini adalah valid.

\section{Hasil Uji Reliabilitas}

Hasil uji reliabilitas menghasilkan angka Cronbach Alpha diatas 0,6 sehingga bisa disimpulkan bahwa seluruh variabel yang digunakan dalam penelitian ini adalah reliabel. 

Tabel 1. Hasil Uji Validitas \& Reliabilitias

\begin{tabular}{|c|c|c|c|}
\hline Variabel & Indikator & r hitung & $\begin{array}{c}\text { Reliabilitas } \\
\text { Alpha } \\
\text { Cronbach }\end{array}$ \\
\hline \multirow{4}{*}{$\begin{array}{l}\text { Kreativitas } \\
\text { (Creativity) }\end{array}$} & 1. Keterbukaan & 0,485 & \multirow{4}{*}{0,664} \\
\hline & 2. Unusual Observation & 0,747 & \\
\hline & $\begin{array}{l}\text { 3. Penemuan dan } \\
\text { pengembangan ide baru }\end{array}$ & 0,751 & \\
\hline & $\begin{array}{l}\text { 4. Keinginan kuat untuk } \\
\text { belajar }\end{array}$ & 0,864 & \\
\hline \multirow{4}{*}{$\begin{array}{l}\text { Inovasi Produk } \\
\text { (Product } \\
\text { Innovation) }\end{array}$} & 5. Kelebihan produk baru & 0,872 & \multirow{4}{*}{0,913} \\
\hline & 6. Produk mudah dikenali & 0,876 & \\
\hline & $\begin{array}{l}\text { 7. Produk diterima oleh } \\
\text { konsumen }\end{array}$ & 0,909 & \\
\hline & $\begin{array}{l}\text { 8. Pengembangan produk } \\
\text { baru }\end{array}$ & 0,907 & \\
\hline \multirow{4}{*}{$\begin{array}{c}\text { Kinerja Usaha } \\
\text { (Business } \\
\text { Performance) }\end{array}$} & 9. Pertumbuhan penjualan & 0,904 & \multirow{4}{*}{0,826} \\
\hline & $\begin{array}{l}\text { 10. Pertumbuhan tenaga } \\
\text { kerja }\end{array}$ & 0,779 & \\
\hline & 11. Pertumbuhan pendapatan & 0,904 & \\
\hline & $\begin{array}{l}\text { 12. Pertumbuhan pangsa } \\
\text { pasar }\end{array}$ & 0,722 & \\
\hline
\end{tabular}

\section{Uji Asumsi Klasik}

a. Uji Normalitas

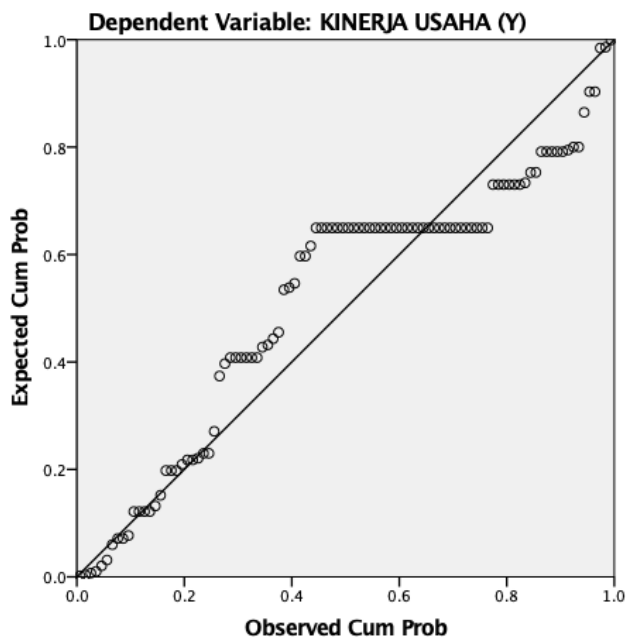

Gambar 2.

Normalitas

b. Uji Multikolinieritas

Model dapat dikatakan terbebas dari deteksi multikolinearitas jika nilai VIF < 10 dan nilai Tolerance $>0,10$. 
Tabel 2. Hasil Uji Multikolinieritas

\begin{tabular}{ccc}
\hline \multirow{2}{*}{ Model } & \multicolumn{2}{c}{ Collinearity Statistics } \\
\cline { 2 - 3 } & Tolerance & VIF \\
\hline & & \\
\hline X1 & .953 & 1.050 \\
\hline X2 & .953 & 1.050 \\
\hline
\end{tabular}

c. Uji Heteroskedastisitas

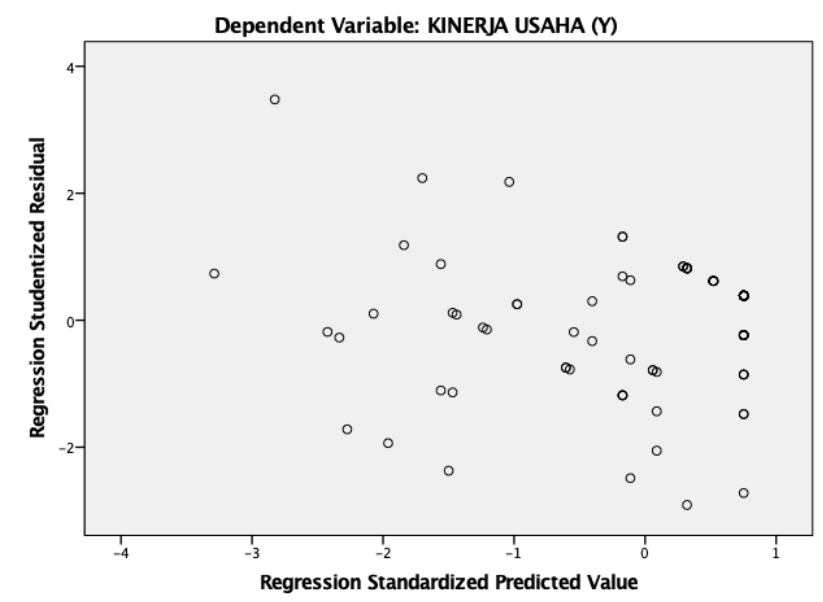

Gambar 3 Hasil Uji Heteroskedastisitas

d. Uji Regresi Berganda

Tabel 4 Hasil Uji Regresi Linier Berganda

\begin{tabular}{|c|c|c|c|c|c|c|c|}
\hline \multirow{2}{*}{ Model } & \multicolumn{2}{|c|}{$\begin{array}{l}\text { Unstandardized } \\
\text { Coefficients }\end{array}$} & $\begin{array}{l}\text { Standardized } \\
\text { Coefficients }\end{array}$ & \multirow{2}{*}{$\mathrm{t}$} & \multirow{2}{*}{ Sig. } & \multicolumn{2}{|c|}{$\begin{array}{l}\text { Collinearity } \\
\text { Statistics }\end{array}$} \\
\hline & B & $\begin{array}{l}\text { Std. } \\
\text { Error }\end{array}$ & Beta & & & $\begin{array}{l}\text { Toler } \\
\text { ance }\end{array}$ & VIF \\
\hline 1 (Constant) & -1.920 & 2.111 & & -.910 & .365 & & \\
\hline $\begin{array}{l}\text { KREATIVITAS } \\
\text { (X1) }\end{array}$ & .694 & .105 & 485 & 6.591 & .000 & .953 & 1.050 \\
\hline $\begin{array}{l}\text { INOVASI } \\
\text { PRODUK (X2) }\end{array}$ & .371 & .065 & .420 & 5.715 & .000 & .953 & 1.050 \\
\hline
\end{tabular}

a. Dependent Variable: KINERJA USAHA (Y)

$$
Y=(-1.920)+0,694 X 1+0,371 X 2+\mathrm{e}
$$

Berdasarkan perhitungan di atas, maka hasil koefisien regresinya bisa dijelaskan sebagai berikut:

1) $\mathrm{Y}=$ Kinerja Usaha; $\mathrm{X} 1=$ Kreativitas; $\mathrm{X} 2=$ Inovasi Produk; $\mathrm{e}=$ Error (variabel lainnya yang tidak terdapat di dalam model)

2) Angka konstanta sebesar $(-1,920)$ artinya saat usaha tidak memiliki kreativitas dan tidak ada inovasi produk maka kinerja usaha akan mengalami penurunan sebesar ($19,2)$ satuan. Kondisi seperti ini umumnya disebabkan karena pasar saat ini 
memerlukan berbagai inovasi produk yang berbeda, inovatif dan sesuai kebutuhan konsumen.

3) Angka koefisien regresi X1 (Kreativitas) sebesar 0,694 maksudnya adalah apabila $\mathrm{X} 1$ naik +1 poin maka akan terjadi kenaikan dalam kinerja usaha yaitu sebesar 0,694 satuan, dengan asumsi variabel lain (inovasi produk) tetap. Koefisien bernilai positif, maka kreativitas memiliki dampak atau mempengaruhi secara positif bagi variabel kinerja usaha.

4) Nilai koefisien regresi $X 2$ (Inovasi Produk) sebesar 0,371 artinya jika $X 2$ bertambah +1 satuan maka akan terjadi peningkatan kinerja usaha sebesar 0,371 satuan, dengan asumsi variabel lain (kreativitas) tetap. Koefisien bernilai positif, maka inovasi produk mempunyai pengaruh positif terhadap kinerja usaha.

\section{e. Hasil Uji Hipotesis}

1) Uji Koefisien Determinasi

Hasil uji koefisien determinasi dalam penelitian ini adalah sebesar 0,490, hal ini menandakan bahwa kinerja UKM di Kota Semarang mampu dijelaskan oleh variabel kreativitas dan inovasi produk sebesar 49\%. Sebanyak 51\% sisanya dijelaskan oleh variabel lain di luar model.

2) Uji Signifikansi Simultan (F)

Uji $F$ dalam penelitian ini digunakan untuk mengetahui pengaruh variabel independen: kreativitas dan inovasi produk secara bersama- sama (simultan) terhadap variabel terikat: kinerja usaha UKM. Apabila nilai signifikan $<0,05$, maka model dapat dikatakan signifikan. Berdasarkan hasil estimasi pada Tabel 5, diperoleh nilai $\mathrm{F}$ hitung sebesar 58,524 dan $\mathrm{F}$ Tabel 2,698 serta nilai signifikansi sebesar 0,0000 yang mana $<0,05$. Maka $\mathrm{H}_{0}$ ditolak dan menerima $\mathrm{H}_{\mathrm{A}}$, sehingga dapat disimpulkan bahwa secara bersama-sama variabel kreativitas dan inovasi produk berpengaruh positif dan signifikan terhadap variabel kinerja usaha UKM di Kota Semarang.

Tabel 5. Hasil Uji F

\begin{tabular}{llrrrrr}
\hline Model & \multicolumn{1}{l}{$\begin{array}{l}\text { Sum of } \\
\text { Squares }\end{array}$} & \multicolumn{1}{c}{ df } & \multicolumn{1}{c}{ Mean } \\
Square & \multicolumn{1}{c}{ F } & \multicolumn{1}{c}{ Sig. } \\
\hline \multirow{2}{*}{1} & Regression & 255.119 & 2 & 127.559 & 48.524 & $.000^{\text {b }}$ \\
\cline { 2 - 7 } & Residual & 254.991 & 97 & 2.629 & & \\
\cline { 2 - 7 } & Total & 510.110 & 99 & & & \\
\hline
\end{tabular}

\section{f. Uji Signifikansi Parsial (Uji t)}

1) Pengaruh kreativitas (X1) terhadap kinerja usaha $(Y)$

Hasil perhitungan diperoleh $t_{\text {hitung }}=6,591$ lebih besar dari $t_{\text {tabel }}=1,985$ dengan sig. 0,000, ini berarti bahwa terdapat pengaruh positif secara parsial antara variabel bebas $\left(\mathrm{X}_{1}\right)$ terhadap variabel terikat $(\mathrm{Y})$. Hasil Uji statistik $\mathrm{t}$ mendukung hipotesis dari penelitian ini yaitu diduga kreativitas mempunyai pengaruh positif signifikan terhadap kinerja. Tanda positif pada koefisien beta menunjukkan hubungan yang searah artinya semakin tinggi tingkat kreativitas maka akan terjadi peningkatan pada kinerja usaha UKM (optimal). 
2) Pengaruh inovasi produk (X2) terhadap kinerja usaha (Y)

Hasil perhitungan diperoleh $t_{\text {hitung }}=5,715$ lebih besar dari $t_{\text {tabel }}=1,985$ dengan sig. 0,000, ini berarti bahwa terdapat pengaruh positif dan signifikan antara variabel bebas $\left(\mathrm{X}_{2}\right)$ terhadap variabel terikat $(\mathrm{Y})$. Hasil Uji statistik $\mathrm{t}$ mendukung hipotesis dari penelitian ini yaitu diduga inovasi produk berpengaruh positif dan signifikan secara parsial terhadap kinerja. Tanda positif pada koefisien beta menunjukkan hubungan yang searah artinya semakin berkualitas inovasi produk maka akan meningkatkan kinerja usaha UKM.

Berdasarkan hasil analisis dapat diketahui bahwa UKM yang memiliki kreativitas dan inovasi produk yang tinggi akan memiliki kemampuan dalam mencapai kinerja usaha yang tinggi pula. Oleh karena itu UKM diharapkan mampu memunculkan kreativitas dan inovasi produk secara berkelanjutan sehingga meningkatkan kinerja usaha yang maksimal.

Kreativitas ditemukan secara positif dan signifikan mempengaruhi kinerja usaha. Temuan ini mendukung penelitian sebelumnya yang dilakukan oleh Rahman, Setyanti, \& Saleh (2015) yang menemukan bahwa kreativitas berpengaruh positif dalam mendukung keberhasilan usaha. Penelitian sejenis juga dilakukan oleh Farisi (2013) yang menemukan bahwa inovasi dan kreativitas memiliki hubungan yang kuat terhadap keberhasilan usaha.

Menurut Hurley, Thomas, \& Hult (1998) inovasi produk merupakan salah satu keunggulan kompetitif dalam meningkatkan kinerja usaha. Temuan penelitian ini didukung Hadiyati (2011) yang menemukan bahwa inovasi memiliki dampak paling besar dalam aktivitas kewirausahaan.

Secara simultan kreativitas dan inovasi juga mampu memberikan pengaruh yang positif dan signifikan dalam upaya meningkatkan kinerja UKM. Sebagaimana penelitian yang dilakukan oleh Anjaningrum \& Sidi (2018); Arifudin (2016) yang menemukan bahwa kreativitas dan inovasi baik secara parsial maupun bersama-sama memiliki pengaruh positif dan signifikan terhadap kinerja dan keberhasilan usaha.

\section{SIMPULAN}

Hasil yang ditunjukkan berdasarkan analisis dan pembahasan secara menyeluruh pada penelitian ini adalah kreativitas dan inovasi produk mampu meningkatkan kinerja usaha UKM secara positif dan signifikan baik secara parsial maupun simultan. Bagi pemilik ataupun pengelola UKM di Kota Semarang diharapkan untuk meningkatkan budaya kreativitas dan inovasi produk sehingga menghasilkan kinerja yang turut meningkat. Pengelola UKM juga diharapkan membangun komunikasi internal yang baik agar proses kreatif dalam menghasilkan inovasi produk bisa berjalan dan berkelanjutan. Tuntutan pasar agar produsen terus menghasilkan produk berkualitas dan inovatif harus direspon dengan cermat dan tepat. Proaktif mendengarkan opini ataupun keluhan pelanggan, serta mencari dan menemukan informasi terkini dari pesaing agar lebih memahami perkembangan pasar.

\section{DAFTAR PUSTAKA}

Abraham, J. L., \& Daniel, J. K. (2002). Strategic innovation: leveraging creative action for more profitable growth. IEEE Engineering Management Review, 30.4, 23-23. Retrieved from https:/www.emeraldinsight.com/doi/abs/10.1108/10878570110694625

Anjaningrum, W. D., \& Sidi, A. P. (2018). Determinan Keunggulan Kompetitif dan Kinerja Industri Kreatif. Jurnal Ekonomi Modernisasi, 14 (1). Retrieved from https://doi.org/10.21067/jem.v14i1.2379 
Arifudin, P. M. (2016). Pengaruh Kreativitas, Inovasi dan Media Promosi terhadap Keberhasilan Usaha Warung Kopi Free Wifi di Kecamatan Wates. Universitas Nusantara PGRI Kediri.

Barringer, B. R., \& Ireland, R. D. (2006). Entrepreneurship: Successfully launching new ventures. New Jersey: Person Prentice Hall.

Bosma, N., \& Harding, R. (2006). Global entrepreneurship monitor: GEM 2006 summary results. Babson College London Business School.

Cook, P. (1998). The creativity advantage-is your organization the leader of the pack? Industrial and Commercial Training, 30.5, 179-184. Retrieved from https://doi.org/10.1108/00197859810225652

Gurteen, D. (1998). Knowledge, creativity, and innovation. Journal of Knowledge Management, $2.1,5-13$.

Hadiyati, E. (2011). Kreativitas dan Inovasi Berpengaruh terhadap Kewirausahaan Usaha Kecil. Jurnal Manajemen dan Kewirausahaan, (8-11).

Hapsari, I. M. (2014). Identifikasi Berbagai Permasalahan yang Dihadapi oleh UKM dan Peninjauan Kembali Regulatasi UKM sebagai Langkah Awal Revitalitasi UKM. Permana, 2 No $5,43$.

Heye, D. (2006). Creativity and innovation: Two key characteristics of the successful 21st century information professional. Business Information Review, 23.4, 252-257.

Hurley, R. F., Thomas, G., \& Hult, M. (1998). Innovation, Market Orientation, and Organization Learning: An Integration and Empirical Examination. Journal of Marketing, 62 Juli.

Jonker, J., Pennink, W, B. J., \& Wahyuni, S. (2011). Metodologi Penelitian: Panduan untuk Master dan Ph. D. di Bidang Manajemen.

Kruger, M. E., Millard, S. M., \& Pretorius, M. (2005). Creativity, innovation and implementation: Management experience, venture size, life cycle stage, race and gender as moderators. South African Journal of Business Management, 36.4, 55-68.

Larsen, P., \& Lewis, A. (2007). "How award-winning SMEs manage the barriers to innovation." Creativity and Innovation Management, 16.2.

Loee, P., \& Dominiquini, J. (2006). Overcoming the barriers to effective innovation. Strategy \& Leadership, 34.1, 24-31.

Rahman, D. K., Setyanti, S. W. L. H., \& Saleh, C. (2015). Pengaruh Kreativitas dan Perilaku Inovatif terhadap Keberhasilan Usaha Industri Kecil melalui Motivasi Usaha Sebagai Variabel Mediasi (Studi Kasus pada Pengusaha UKM Kerajinan Bambu di Desa Gintangan Kabupaten Banyuwangi). Universitas Jember.

Stel, A. Van, Carree, M., Thurik, R., \& Zoetermeer. (2004). The Effect of Entrepreneurship on National Economic Growth: an Analysis Using the GEM Database. Scales Paper, No. 320. 